\title{
Integration of Art and Morality in Oscar Wilde's the Happy Prince
}

\author{
Ali Hafudh Humaish \\ Department of English Language and Literature, College of Education, Wasit University, Wasit, Iraq
}

\section{Email address:}

alihumaish@yahoo.com

\section{To cite this article:}

Ali Hafudh Humaish. Integration of Art and Morality in Oscar Wilde's the Happy Prince. English Language, Literature \& Culture. Vol. 2, No. 1, 2017, pp. 5-11. doi: 10.11648/j.ellc.20170201.12

Received: March 3, 2017; Accepted: March 14, 2017; Published: March 28, 2017

\begin{abstract}
Oscar Wilde is associated with the doctrine Art for Art's sake. He is believed to be a pure aesthete who thought of morality as being independent of art. Critics often describe the decadence literature to which Wilde belongs as being immoral, morbid, sordid, and perverse. Some critics find his story The Happy Prince an example of his homosexuality. In his short story The Happy Prince he proved to be more a moralist than an aesthete. It shows that he did not in fact apply his doctrine Art for Art's Sake. The paper shows that Wilde also believed in the inherently moralist nature of art. He believed that art can transform society into a better one through better appreciation of art. Art may also create the conditions conducive to a further development of a society. Drawing a grim picture of a town where art is not appreciated, he presents the theory that a modern welfare state cannot be constructed without art. He charts the way towards achieving such a project. He makes a statue transform a misery-stricken town into a happy one. Thus he criticizes the crude Victorian society and their hostility to his theory of aesthetics as well as their obsession with the new materialism and ugly industrialization of the age. He indicts inequality, poor living conditions and misery. The Happy Prince is a celebration of the importance of art in any modern society. He concludes his story with the idea that religion does not disapprove of art making the story his proof that he does preach morality in his art and he is far from being morbid or perverse.
\end{abstract}

Keywords: Art for Art's Sake, The Happy Prince, Wilde's Art, Wilde's Aesthetic, Wilde and Pater

\section{Introduction}

Oscar Wilde is called the father of the English decadence. The term 'decadence' was used in the last decade of the 9th century under the influence of the French decadent writers. Though excess, artificiality, morbidity and amorality are major characteristics of the decadent movement, Wilde shows that he is in the opposite direction of the movement. $\mathrm{He}$ is an aesthete who believed in the power of art in effecting a change in the life of the individual. It is only his scandal that stigmatized him as a decadent writer. He is often remembered for the scandal of his homosexuality for which he was imprisoned for committing 'a gross indecency' which precipitated his downfall. He was torn between two choices, John Ruskin and the moral and didactic nature of art on the one hand and Walter Pater's purely aesthetic and hedonistic influence under his manifesto 'Art for Art's sake'. Pater believed that the shortness of life encourages an indulgence in pleasure to maximize the ecstasy. Pater believed: as Victor
Hugo says: we are all under sentence of death but with a sort of indefinite reprieve-les hommes sont tous condamnes a mort avec des sursis indefinis: we have an interval, and then our place knows us no more. Some spend this interval in listlessness, some in high passions, the wisest, at least among "the children of this world," in art and song."(Pater, The Renaissance, p. 120)

Though Wilde expounded his theory in his Essays, and was known to be an advocate of Pater's doctrine, he did not put this doctrine in practice. His works show him a Ruskinian moralist who strongly believed in the supremacy of art as a philosophy that can make a big difference in life. This, however, does not mean that pursuing beauty and pleasure is immoral, decadent or artificial. He asserts that pleasure is the only thing worth having a theory about," he answered in his slow melodious voice. "But I am afraid I cannot claim my theory as my own. It belongs to Nature, not to me. Pleasure is Nature's test, her sign of approval. When we are happy, we are always good, but when we are good, we are not always happy." [13]. 
Oscar Wilde expounds in his short story The Happy Prince his aesthetic and moral theory which revolves around the integration of art into morality as a prerequisite for creating a healthy and prosperous socialist society in application of his theory elucidated in his essay The Soul of Man under Socialism. Despite the fact that his theory was often misunderstood by numerous hostile critics who accused him of stripping art of its indispensable moral code under the doctrine of Art for Art's sake, he proves in this short story that not only does his aesthetic theory transcend time, space and relativity to which morality is often subjected, but that art is indispensable in creating the mood and individuality that may promote the creation of a socially prosperous society. In the last episode of the series if events in the story Wilde resolves the contention that his art is inherently immoral and decadent with the idea that religion does not frown on his art for being too much indulged in hedonism and Epicureanism. He assures his readers towards the end that the artist as a creator will always have the approval of the God, the Supreme Creator.

\section{Critical Analysis}

Russel M. Goldfarb is not the only critic who described the decadence movement in literature in pejorative terms. Many critics tend to repeat this criticism. He summarized, however, some of the major characteristics which are associated with the movement and which was also a summary of the mainstream criticism of the movement. He states that this literature: does not emphasize philosophical, historical, or intellectual concerns, but does emphasize the values to be gained both from experience of all sorts and from indulgence in a life of sensations. Because of this emphasis, decadent literature is animated by the exploration of immoral and evil experiences; never does it preach morality, nor does it strongly insist upon ethical responsibilities. Decadent literature is characterized by artistic concern for the morbid, the perverse, the sordid, it is characterized by a selfconscious and weary contempt for social conventions such as truth and marriage. [2].

Wilde who belongs to the movement proves, however, in his work in general and in his short story The Happy Prince in particular the apposite of such statements. Indeed he questions the very basis upon which such criticism is based, which is the doctrine of art for art's sake. A doctrine which mistakenly almost entirely separates morality from art. Wilde in this story is not only a moralist but he also expounds his theory that art and free imagination are integral parts of the moral code and an indispensable element that should integrate the moral code of any given society.

Happy Prince relates the story of a prince who was living in a palace of luxury where he did not feel the suffering of his townspeople. He was so happy that he was called The Happy Prince. After his death the town councilors made him a statue and covered him with gold and precious stones. The statue was set up high in the city where he could now see the misery of the town. The statue then comes to life and befriends a swallow. He solicits the help of the swallow to take the precious stones and gold in order to give to the poor townspeople.

Wilde's doctrine, however, Art for Art 's sake seems to be entirely absent from the Happy Prince. Wilde learned from Ruskin that art should tell a truth and from Pater that it should be only beautiful and not to be critiqued. He managed to combine both. Though he did resort to Paterian sensations to evoke a vision of happiness for the town people of the happy prince. But he departed from the mere sensational critique of art to advocate a vision full of moralizing and deep moral and social consciousness. As a typical aesthete Wilde would not limit himself to creating a mood or sensation: "French and English 'aesthetes' held that art should not be educative, that art's purpose is to create a mood or a sensation and not to advocate moral propositions; art need only fulfil possibilities of beauty inherent in any art form." [4]. Wilde incorporated into his work the beauty of this aesthetic sensation with morality.

The story is part of juvenile literature that Wilde wrote to entertain children. It is, however, appealing to both, children and adults alike. He maintained that it appeals to both children and adults albeit the themes involved look beyond the comprehension of children. It is " meant partly for children, and partly for those who have kept the childlike faculties of wonder and joy, and who find in simplicity a subtle strangeness". [1]. It is a fairy tale with typical characteristics that even qualify it as a fable: features like talking animals, happy ending, fantastic events, obvious good and evil forces and a setting in the past. His choice of a fairy tale is apt as it gives him time and space to reflect his favourite Paterean idealisation of art with freedom and with a difference as well: Pater's aesthetic credo in 'The Renaissance' clearly informs Wilde's fairy tales. Wilde, however, is too independent an artist to simply echo Pater's words: he extends their implications to life, and critiques reflexively by demonstrating both the pleasure and perils of such an ethos." [8].

Wilde wanted to directly reflect on modern life while keeping live his aesthetic concerns. He wrote to a friend that the story is "an attempt to mirror modern life in a form remote from reality--to deal with modern problems in a mode that is ideal and not imitative" [9].

This tale, unlike the Selfish Giant, for example is meant to entertain a judicious audience. In the story Wilde proposed his theory of reconstructing welfare socialist society on the basis of several essential elements. The first is to improve the conditions for the working classes and secondly, he suggests supporting creative people and the promotion of creativity. He also believed that child labour of the Victorian age was a pressing problem that the system failed to address. This is indeed reminiscent of Dickens' criticism of the living conditions of children and Blake's 'the Chimney Sweeper' as well. He believed that children are the future of any society and no theory can meet with success unless children's living conditions are drastically improved. Lastly he calls for a system of social assistance to the needy in order to help them 
rebuild their life without having to compromise their dignity. All of the afore-mentioned proposals are present in the symbolism of the Happy Prince. He made, however, art as the basis of his theory and a prerequisite for making the welfare state. Lack of art in a given society will hinder the creative process of man which is indispensable to achieve the aims outlined above.

This particular short story was much debated by critics. Most of them failed to touch the real essence of the story. Reading the story as an example of Wilde's homosexuality or trying to prove that the story is a reflection of the Marxist socialist theory looks lop-sided if not too obtrusive as such theories reflect only one episode in the story without fitting all together to produce the entire effect. The story needs to be read and evaluated as one whole piece and focusing on one part only makes it all the more misleading to understand Wilde's real intention. Wilde unavoidably shows the Victorian reality and proposes solutions. He serves as a social critic like Dickens for example "to see the unhappy truths about material/historical reality, for whether or not authors intend it they are bound to represent socioeconomic inequities and ideological contradictions" [7]. His solution only takes art as a pivotal solution to the inequalities of the society. At the beginning of the story, our attention is drawn to the statue of the Happy Prince:

High above the city, on a tall column, stood the statue of the Happy Prince. He was gilded all over with thin leaves of fine gold, for eyes he had two bright sapphires, and a large red ruby glowed on his sword-hilt. [14].

Wilde chose a statue to be the major character in the story. It is easy, however to recognize that the statue stands for art as artistic works, memorials and monuments are set up to immortalise a person or an event. Wilde is conscious of immortality of art as much as the Nobel Laureate W. B. Yeats. This is, in fact, reminiscent of his poem Sailing to Byzantium where in the last stanza the poet says that if her were to choose another life he would prefer to be a long living statue rather than a mortal human because life is short and art lives much longer than living humans:

Once out of nature I shall never take

My bodily form from any natural thing,

but such a form as Grecian goldsmiths make

of hammered gold and gold enameling

To keep a drowsy Emperor awake;

Or set upon a golden bough to sing

to lords and ladies of Byzantium

of what is past, or passing, or to come. [17].

Wilde starts his story with a non-conventional story telling He did not start it like any other fairy tale with phrases like once upon a time or there lived once. But he immediately drew our attention to the statue of the Happy Prince placing an adverbial phrase at the beginning of the story. He put thus his emphasis on the pivotal character of his story. The prince statue was beautiful and covered with expensive jewels, sapphires, gold and ruby. It stands as a symbol of artistic perfection as it was admired by people despite the fact that the townspeople do not seem to be happy "I am glad there is someone in the world who is quite happy", muttered a disappointed man as he gazed at the wonderful statue though he is too unhappy to be in a position to express any form of admiration. Paradoxically the Happy Prince contrasts with a miserable town ruled by the town councilors who turn later to be mere hypocrites. The use of the word "happy" in the story is ironically used to accentuate the opposite of what it really means. It is revealing and it foreshadows a society with numerous contradictions.

He was very much admired indeed. He is as beautiful as a weathercock,' remarked one of the Town Councillors who wished to gain a reputation for having artistic taste; 'only not quite so useful,' he added, fearing lest people should think him unpractical, which he really was not. [14].

The misery of the town is obviously caused by the town councillors themselves, by their selfishness, greed and hypocrisy. The town councillor's initial remark was to show his interest in art. He assumes that art should be useful and if it is not, then it is useless. That beauty without a moral message is useless is already inculcated into the Victorian consciousness. Wilde wrote in his preface to his novel The Picture of Dorian Grey that "all art is quite useless" [16]. His remark is similar to the remark of the town councillor though in practice he made the statue assume heavy moralising responsibilities. He even affirms himself further when he says that authoritarian regimes fear individualism that art inspires. He remarks that "it is to be noted that it is the fact that Art is this intense form of Individualism that makes the public try to exercise over it in an authority that is as immoral as it is ridiculous, and as corrupting as it is contemptible." [13].

The town councillor's remark comparing the statue to a weathercock is ridiculous. The weathercock turns left and right to show the direction of the wind, a function which is so insignificant that the remark is only meant to help diminish the value of the statue. Paradoxically the councillor himself is as changeable as a weathercock. An authoritarian, however, does not see in art more value than that of a weathercock. Wilde meant this statue to represent art in all its grandeur, beauty and precious value. There is no wonder why Wilde decorated the statue with the most precious stones. Art for Wilde was even more precious than the precious stones that covered the statue and it is art that would eventually transform the town of the Happy Prince, not alone though. He often associated beauty with precious stones as he strongly believed that these stones are symbols of permanence and beauty is permanent.

Art belongs to imagination in the first place. Imagination under this authoritarian regime is forbidden. The town does not approve of dreaming. Therefore the mathematical master frowned when he heard that the school children saw an angel that looks like the Happy Prince in their dreams " "Ah! but we have, in our dreams,' answered the children; and the Mathematical Master frowned and looked very severe, for he did not approve of children dreaming." [14]. Dreaming is not allowed in the selfish town and children are not allowed to dream as this may threaten the very existence of the 
governing elite and because there is no art without imagination and dreaming, so is art doomed not to exist in the impoverished town before the reawakening that the beauty-inspired soul of the Happy Prince will later trigger off.

With this setting in mind we are then introduced to the second character in the story which is the romantic Swallow. $\mathrm{He}$ is idealistic by nature and realistic at the same time. For though he fell in love with the reed because he had admired her slender waist but he still decided at the end to leave her because he thought that such a relationship is " a ridiculous attachment" because he likes to travel and fly and she is static and cannot move. She is a coquette who flirts with the wind and she does not have a conversation and has no money as well. We get to see more and more character traits of the Swallow. As he flies to the town he wonders if the town has made any preparations for him. He is proud, vainglorious and snobbish expecting the town to celebrate his coming. As he decides to put up between the feet of the statue of the Happy Prince, he sees a drop of water fall from him. He remarks that 'What is the use of a statue if it cannot keep the rain off? [14], he said; 'I must look for a good chimney-pot,' [14]. A dirty chimney pot is for him more protective than a statue covered with precious stones. The character traits of the Swallow are symbolic of any ordinary average Victorian personality with typical pride, realism, idealism with a typically Victorian lack of appreciation for aesthetic objects preferring a useful chimney to a useless golden statue. The knowledge to appreciate art will gradually transform him. The statue begins to tell his story to the Swallow. He tells him that behind the walls of the palace, he enjoyed all types of pleasures and he was happy if sensual pleasure can be named happiness. When he was a living human the Happy Prince was not able to feel the misery and suffering of the town people as he was too engaged with carnal and sensual desires. He was able to attain some kind of self-denial or altruism only when he assumed an artistic shape. He only knew tears when he became a piece of art. Art has transformative powers capable of changing the soul of the prince into a different more sensible, more altruistic one.

In this context art is about to change the Swallow as well and turn him into a new more sensible and more caring character. He asks him to take the ruby out of his sword-hilt and give it to the poor toiling seamstress who is embroidering passion-flowers for the queen's maid-of-honour. Her hands were red and her face was worn and thin. In fact the word passion is symbolic of the passion of Christ; the suffering of Christ on the cross during the crucifixion. Wilde regarded Jesus the inimitable supreme romantic artist. The queen and her entourage do not know what art is, they also do not feel others' suffering as Jesus did. They know art as a mere decoration. The passion in this context is entirely different. Paradoxically it is only to be embroidered on the satin gown to please the rich queen. Religion is here referred to as being used for fake appearances only and not for the sake of the prosperity of humanity. Wilde criticises the religious hypocrisy of the Victorian age. The rich use religion to feed on the poor and only as a piece of decoration to beatify their appearances.

But at first the various desires and wishes of the vain Swallow prevent him from fulfilling the request of the Happy Prince. He says that he is being waited for in Egypt where the weather is warm. His friends are flying up and down the Nile talking to the lotus-flowers and he begins enumerating all types of pleasure he is likely to miss in case he accepted the Happy Prince's request. He again justified his refusal by the fact that he hates boys because Last summer, when I was staying on the river, there were two rude boys, the miller's sons, who were always throwing stones at me. They never hit me, of course; we Swallows fly far too well for that, and besides, I come of a family famous for its agility; but still, it was a mark of disrespect.' [14].

As mentioned earlier, the Swallow represents the morality of the crude Victorian age. Pride, conceit, egotism and dignity and noble descent are reflected in the character of the Swallow. All of them are traits inherent in the Victorian society that block people from accepting art and beauty as essential and indispensable for society change for the better. What the Swallow lacks is only susceptibility to let art enter his heart and transform him so that he can be an altruistic creature feeling the suffering of the needy and shaking off hypocrisy. The Swallow, however, reluctantly acquiesce to the request of the Happy Prince at first when he sees his sadness. He picked up the ruby and flew over the town to give the ruby to the poor seamstress. While flying he passed by a balcony of a beautiful woman speaking with her lover about the power of love. She says that she ordered passion flowers to be embroidered on her dress but the seamstress was too lazy. Wilde lingers again over the image of insensibility of the rich to the poor. He shows their selfish and narcissist nature. Ironically, the lovers speak about love. They do not know true love. True love is not merely love of pleasures. The kind of love that the Happy Prince had known during his life time was not true love. True love is sacrifice and self- denial to attain spiritual perfection that leads to true happiness. Wilde was at pains to make this concept clear. His use of irony to reveal hypocrisy is poignant.

In appreciation of the hard work of the seamstress the Swallow placed the ruby beside the thimble-not anywhere else- and hovered around the feverish boy and with his wings fanned the boy who felt better. The first transformation that the Swallow underwent was his feeling warm in the cold weather. 'That is because you have done a good action,' was the answer of the Happy Prince. Art is changing the vainglorious Swallow. Individualism is one of the prerequisites of art as Wilde clearly stated in his essay The Soul of Man under Socialism. He emphasised the importance of being unique in the society as imitation spoils the diversity of the human race: whenever a community or a powerful section of a community, or a government of any kind, attempts to dictate to the artist what he is to do, Art either entirely vanishes, or becomes stereotyped, or degenerates into a low and ignoble form of craft. A work of art is the 
unique result of a unique temperament. Its beauty comes from the fact that the author is what he is. [13].

The change began with the Swallow who became the incarnation of uniqueness and individual change. He is no longer a conformist who blindly complies with the mores of the society. He is now more sensible, more willing to accept the errands of the Happy Prince. An action which is sharply contrasted with the love of the two lovers at the balcony. Sensual love is placed against spiritual one. A conflict between sensual pleasures and spiritual ones that the Swallow resolved in favour of spiritual love. In reality the statue or, in other words, art has not only made an atmosphere conducive to change but served as a moralizing agent preaching morality and spirituality.

The professor of ornithology who wonders at seeing a Swallow in winter and writes a long article to the press explaining this extraordinary phenomenon with words that many of the public did not understand. Not every Victorian, however, was ready to accept what Wilde was doing at any rate. Many did not understand what he was doing with his new style, aesthetics and seemingly eccentric dress. It was undoubtedly an extraordinary phenomenon at the time to understand sacrifice.

The Happy Prince asks the Swallow again to help him. Repeating his delicate and poetic phrase "Swallow, Swallow, little Swallow" he implores the swallow to help a dramatist. But this time the prince has no ruby to give but he does have sapphires in his eyes. $\mathrm{He}$ is willing to give his eyes to creative people like the dramatist. Having helped the hard working people, or in other words the working classes and rewarded them for their hard work in order to promote their individualism and protect them against poverty, it is time for Wilde to reward creative people for their imagination in the hope that children may start dreaming again. The healthy construction of a good society starts with a similar care to children, their dreams, and the cultivation of their imagination. Imagination can help those children dream of building a better future. The dramatists and novelists, writers and authors represent the intelligentsia of every society and without them a society cannot be reformed. He gave his eyes to the dramatist so he can finish writing his play. 'I am beginning to be appreciated,' he cried; 'this is from some great admirer. Now I can finish my play,' and he looked quite happy. [13].

Feeling sympathetic for the Happy Prince, the Swallow promises him that when he goes to Egypt he will bring him back more beautiful and more shinning jewels than the ones he had given to town people. The choice of Egypt is not without its symbolic significance. The Greek and Egyptian civilizations both fascinated Wilde and he regarded them emblems of beauty, a storehouse of exotic and aesthetic objects. But the prince implores him again and asks him to listen to his command. The word "command" is a deliberate play on the word commandment used in the bible. The religious connotation of the word here is inescapable. Wilde regarded Christ a supreme artist: To the artist, expression is the only mode under which he can conceive life at all. To him what is dumb is dead. But to Christ it was not so. With a width and wonder of imagination that fills one almost with awe, he took the entire world of the inarticulate, the voiceless world of pain, as his kingdom, and made of himself its eternal mouthpiece. Those of whom I have spoken, who are dumb under oppression, and 'whose silence is heard only of God,' he chose as his brothers. He sought to become eyes to the blind, ears to the deaf, and a cry in the lips of those whose tongues had been tied. [13].

It carries the message that art is real religion as if the Happy Prince is asking him in the name of what he the Swallow believes in, in the name of religion to stay with him one more night to help him reform a society in wretched conditions. Pearson called Wilde's fairy tales "Lessons in Practical Christianity". As the Happy Prince gets rid of all of his precious possessions, he reminds us of a statement by Jesus Christ related by Wilde in his essay The Soul of Man under Socialism of the rich man who came to Jesus seeking advice Jesus advised him:

'You should give up private property. It hinders you from realising your perfection. It is a drag upon you. It is a burden. Your personality does not need it. It is within you, and not outside of you, that you will find what you really are, and what you really want'[13].

At this point he asked him to pluck his other eye and give it to a little girl selling match- sticks. Her father would beat her if she comes back without money because she had lost her match-sticks in the gutter and there is no way she could bring them back. He helps the poor girl and she goes home happy. Wilde regarded children the backbone of any healthy society and the basis for making a true change in the town was to start giving children a carefree happy life. Child labour has been and is still in some developing countries a real problem and an issue that many governments failed to address.

The Swallow resists all the sensual pleasures awaiting him in Egypt. He is now capable of resisting desires for a higher more sublime objective. He undergoes true transformation in the face of carnal and sensual pleasures and in favour of spiritual happiness. He begins to tell the prince of the stories and marvellous things in Egypt: He told him of the red ibises, who stand in long rows on the banks of the Nile, and catch gold fish in their beaks; of the Sphinx, who is as old as the world itself and lives in the desert, and knows everything; of the merchants, who walk slowly by the side of their camels, and carry amber beads in their hands; of the King of the Mountains of the Moon, who is as black as ebony, and worships a large crystal; of the great green snake that sleeps in a palm-tree, and has twenty priests to feed it with honeycakes; and of the pygmies who sail over a big lake on large flat leaves, and are always at war with the butterflies. [14].

But all of those beautiful stories do not really interest the Happy Prince as he is no longer interested in any sensual pleasures. He tells the Swallow that 'more marvellous than anything is the suffering of men and of women. "There is no Mystery so great as Misery.'Fly over my city, little Swallow, and tell me what you see there." Wilde regarded the suffering 
of men and women a mystery as it is quite ambiguous for him why human beings wrong each other in such a way that one group should live in poverty and misery while a few people accumulate fortunes and private property which he regarded the nightmare of a solidarity community. It is another way of asking why we cannot overcome our selfishness and share with our fellows our fortune. The prince when he was a human was not able to feel the suffering of others. He only felt empathy when he turned into a work of art. The Swallow tells him of what he had seen in in the town, the poor people and the beggars in the streets. This prompts the Happy Prince to ask him for one last errand which is to give the gold that covers his body to the poor to alleviate the suffering of the poverty-stricken town. The gold being less precious than sapphire or ruby is given to the poor classes of the society. More precious stones were given to the dramatist. Writers and people with imagination are better equipped to lead society to prosperity. The Swallow, however, picked his gold 'Leaf after leaf of the fine gold he brought to the poor, and the children's faces grew rosier, and they laughed and played games in the street. 'We have bread now!' they cried. Wilde would certainly forget that social assistance to support the needy is a corner stone for making people live happily. Having done all the commands of the Happy Prince, the people now live happily and:

The streets looked as if they were made of silver, they were so bright and glistening; long icicles like crystal daggers hung down from the eaves of the houses, everybody went about in furs, and the little boys wore scarlet caps and skated on the ice. [14].

The relationship between the Happy Prince and the Swallow develops and the Happy Prince declares that he loves him. Though the Swallow becomes older and colder but he refuses to leave the Happy Prince. The arrogant and proud Swallow has been entirely changed by the Happy Prince. His concerns are no longer love, warmth, Egypt and rest or pleasure or the sensations that he always describes, but he is now determined not to leave the Happy Prince. He told him that he would not go to Egypt but to the house of death. Spiritually the Swallow finds his rest in death which he calls the "brother of sleep".

The statue gets rid of all of its precious stones for the sake of the different classes of the society. Wilde asserted in his essay the Soul of Man under Socialism that when property concentrates in the hands of a few people at the expense of others, this will lead to hindering the natural developments of people and their individual characters:

But it may be asked how Individualism, which is now more or less dependent on the existence of private property for its development, will benefit by the abolition of such private property. The answer is very simple. It is true that, under existing conditions, a few men who have had private means of their own, such as Byron, Shelley, Browning, Victor Hugo, Baudelaire, and others, have been able to realise their personality more or less completely. Not one of these men ever did a single day's work for hire. They were relieved from poverty. They had an immense advantage. It will benefit in this way. Under the new conditions Individualism will be far freer, far finer, and far more intensified than it is now. I am not talking of the great imaginatively-realized Individualism of such poets as I have mentioned, but of the great actual Individualism latent and potential in mankind generally. For the recognition of private property has really harmed Individualism [13].

As the mayor of the town finds that the statue became shabby and ugly and all his precious stones were removed, he decides to have it removed. It is no longer beautiful and therefore it is not useful any more according to the Victorian way of thinking. Wilde was aware of the insensitivity of the Victorian age to his proposals and he does expect a reaction like melting down the Happy Prince. The town councillors and the public in general "utterly failed to perceive the significance of the Happy Prince's transformation. The brisk insensitivity of human characters- or at least the powerful or and learned among them- gives 'The Happy Prince' a tone of scepticism" [5]. The disregard of what the Happy Prince and Swallow have done is a clear indication of either the Victorian misunderstanding of aestheticism or their inability to understand that art and beauty do have a purpose beyond being simply there to stand as an exhibition object.

A university art professor remarks that as the statue is no longer beautiful, so it is no longer useful. Wilde in fact neither identifies himself with the town councillors nor with the university professor who is supposed to represent the educated people. The educated classes conform to the mores, habits and ways of thinking of the common people to satisfy authority. Wilde reflects on the Victorian utilitarian view of art that judges beauty by usefulness. The Victorians believed that we only enjoy beauty as a utilitarian means for an end and nothing beyond that. Wilde, however, believed that art and beauty help create a mood and a sensation that transforms man's vision and helps him look at the world from a different perspective. Beauty can make man create another level of beauty that goes beyond the crude beauty of nature. This helps us understand that Wilde believed in the supremacy of art to nature and even to morality. He reiterates on more than one occasion that life should imitate art and not the opposite. Art is a philosophy that is not relevant as morality is. Using terms from Plato's philosophy, Wilde regarded art as a vision that looks away from the parochially minded people. He asserts in his essay the Decay of Lying that: Remote from reality and with her eyes turned away from the shadows of the cave, Art reveals her own perfection, and the wondering crowd that watches the opening of the marvelous, many-petalled rose fancies that it is its own history that is being told it, its own spirit that is finding expression in a new form. But it is not so. The highest art rejects the burden of the human spirit, and gains more from a new medium or a fresh material than she does from any enthusiasm for art, or lofty passion, or from any great awakening of the human consciousness. She develops purely on her own lines. She is not symbolic of her own age. It is the ages that are her symbols. [10]. 
He indeed identifies himself with the statue and the Swallow who stand as symbols of the transformation that art can exercise on people. Towards the end, the fairy tale turned into a parable with distinct instructive lessons. The Happy Prince and the Swallow were rewarded by God. When God asked his angels to bring him the most precious things, the angels rightly chose the lead heart of the Happy Prince and the dead Swallow. God said 'You have rightly chosen,' 'for in my garden of Paradise this little bird shall sing for evermore, and in my city of gold the Happy Prince shall praise me.'[14]. God rewarded both of them with paradise which is a sign that religion does not disapprove or contradict art. The perfection attained through art is similar to that of religion. The Happy Prince has sacrificed everything without waiting for a reward from others. Like Christ, he was not waiting for a reward and remained anonymous to the very end of the story while those whom he had helped did not think that the help came from the Happy Prince and he himself never asked about the reactions of the towns people for whom he had dismembered himself. He was perfectly altruistic. The mystery he had mentioned earlier in the story regarding people's suffering and the reason why suffering is such a mystery is now cleared. Guy Willoughby comments on the similarity between the figure of Christ and the Happy Prince in sacrifice: In wider social terms, such charitable gestures may be useless, but in individual terms, the terms in which Christ realized himself fully, such sacrifices are vital. When he divests himself of his wealth, the Happy Prince, and not his community, becomes the recipient of grace--or 'perfection', to use the more numinous Wildean term. He is akin to a Gospel character whom Wilde would introduce into both of his later theoretical discussions of Christ. [11].

\section{Conclusion}

Wilde assumes that the fortunes and the material possessions spoil the soul of man. Getting rid of material possessions for the sake of others is a form of individual self -realizations and a development of individuality that lead to an attainment of spiritual beauty that the Happy Prince only attained when he divested himself of his possessions. The superficial appearance of the statue at the end of the story was ugly and shabby, though his soul has attained a perfection of beauty that the superficial utilitarian materialistic town councilors and the Victorians for that matter were not able to appreciate and they are likely to continue to see him as ugly as long as they do not fully understand the real worth of art and only looks at its utilitarian aspect which makes them even worse than they really are in the eyes of the aesthete Oscar Wilde who proved that he is not amoral in his aesthetic theory and that morality not only matters to the artist but that his philosophy of art is a supreme religious realm that involves beauty and morality at the same time.

\section{References}

[1] Ellmann, Richard. Oscar Wilde. New York: Alfred A. Knopf, 1988.

[2] Goldfarb, Russell M. "Late Victorian Decadence," Journal of Aesthetics and Art Criticism, XX,(Summer, 1962), 369-37.

[3] Pater, W. (1980). The Renaissance: Studies in Art and Poetry (D. L. Hill, Ed.). California: First Edition.

[4] Quintus, John Allen. The Moral Implications of Oscar Wilde's Aestheticism. Texas Studies in Literature and Language. 22. 4. University of Texas Press, 1980.

[5] Raby, Peter. (1988). Oscar Wilde. Cambridge: Cambridge UP. Smith, Philip E. (2010). "Approaches to Teaching the Works of Oscar Wilde", Review by Colin Carman Rocky Mountain Review, Vol. 64. No. 1, (Spring).

[6] Sumbul, Yigit. 'WILDE' TIMES: A Marxist Reading of Wilde's The Happy Prince'. Pamukkale University Journal of Social Sciences Institute 2014. 19 (2004).

[7] Tyson, Lois. (2006). Critical Theory Today, 2nd Edition. New York: Routledge. Waldrep, Shelton. (1996) "The Aesthetic Realism of Oscar Wilde's Dorian Gray", Studies in the Literary Imagination, 29.1, Spring, Georgia State University.

[8] Wood, Naomi. (2002) "Creating the Sensual Child: Patron Aesthetics, Pederasty, and Oscar Wilde's Fairy Tales." Marvels and Tales. 16. 2. Wayne University Press.

[9] Wood, Naomi. (1962) The Letters of Oscar Wilde. ed. Rupert Hart-Davis (London: Hart-Davis, 1962).

[10] Wilde, Oscar "The Decay of Lying, in his Intentions, Ed. R. B. Ross (1891; rpr. London: Methuen, 1909.

[11] Willoughby, Guy. (1987) "The Figures of Christ in the Works of Oscar Wilde." Diss. The U of Cape Town, 1987.

[12] Wilde, Oscar. De Profundis. Adelade: U. of Adelade, 2014. ebook.

[13] Wilde, Oscar. (2014) The Soul of Man under Socialism (Second ed., The Project Gutenberg). Retrieved February 07, 2017.

[14] Wilde, Oscar. The Happy Prince and Other Tales. Champaign, III: Project Gutenberg. 1997.

[15] Wilde, O. (2014). The Picture of Dorian Grey (Gutenberg series) [3rd Edition]. Retrieved February 06, 2017, from http://www.gutenberg.org/files/174/174-h/174-h.htm

[16] Wilde, O. The picture of Dorian Grey. London: Edimat Books. (2004).

[17] Yeats, W. B. The collected Poems of W. B. Yeats. Wordsworth Edition. UK, 1994. 